\title{
Traditional medicine and bone grafting
}

\author{
Ochilova Oydina ${ }^{1}$ \\ ${ }^{1}$ Karshynsky's independent applicant state university, Uzbekistan \\ Email: ochilova_oydina@umail.uz
}

\begin{abstract}
This article analyzes the role and activities of the representatives of the direction of "bone marrow" in traditional medicine. Including the practice of folk treatment, and their rational actions, based on the results of centuries of elemental experience of the people.
\end{abstract}

Keywords: Bone-rights, folk medicine, potions, mummies, manuscripts, shepherd, heritage, mouth.

\section{INTRODUCTION}

In modern conditions around the world, interest and attention to traditional medicine is growing. A special interest in traditional medicine is usually primarily associated with purely repetitive goals, which is clearly manifested not only in the sphere of everyday consciousness, but also in science. Attention specifically to these aspects of traditional medicine is quite natural. But along with them, the study of traditional medicine has other tasks, stipulated, in particular, by the fact that it is an indispensable part of the traditional - everyday culture.

In Uzbekistan, during the years of independence, the study and implementation of the traditions of traditional medicine, which is the main component of national and religious values, has become one of the most pressing problems. It would be appropriate here to quote the statements of the President of the Republic of Uzbekistan I. Karimov: "We believe that the revival of spiritual values is a continuous natural process of growth of national self-consciousness, a return to the sources and roots of folk spirituality." In the conditions of independence, paying great attention to folk medicine as the values of the past, wide open space for the activities of the healer. In particular, real actions are being taken in the field of studying the activity of chiropractors, who are one of the main representatives of traditional medicine.

\section{MAIN PART}

In Central Asia, people involved in bone cutting were called "shikastband", "soluvchi", "mouth". The services of chiropractors were used for fractures and exits of human bones. Several types of this craft were distinguished; there were chiropods treating fractures of the lower back of the arms and legs of the human body.

For example, these healers were called by the Russians $<<$ chiropractors $>>$, among the Kazakhs $\langle<$ sinikschi $\gg$. They treated patients with massage, bandages, exercise, and healing herbs. Bone-healers - healers had great prestige among the people, they were respectfully called "mouth". $\ll<$ A healer or a hakim is a specialist doctor (or rather a craftsman) ... they had unlimited trust, great authority, attention and respect not only among the ordinary local population, but among a large number of educated people, they could be reached without a queue, easily and just. He (the healer) knew very well to be, the language, customs, psyche of the local population ... he personally made medicinal drugs, 1 interrupted his connections with the pain, visited the ego several times a day, watched the ego recover >>. The scientist I.K. healers of Central Asia. This characteristic applies to chiropractic.

Some chiropractors, knowing well the human anatomy and physiology, also had strong knowledge of the structure of bones, bone fluid, muscles, and blood vessels. They did not use any medical devices and apparatus. In the treatment of patients, they gave particular preference to dist. Recommended more often to use hot milk, meat, honey, eggs, butter. But categorically forbidden to use fruit in writing.

Bone-graders also absolutely did not recommend applying plaster. They believed that gypsum complicates blood circulation, delays the time of treatment, and prevents control of the process of bone restoration. They advised patients to bathe in salted water and dig into the sand. 
Bone-graders, relying on the millennial experience of many generations, were able to find healing plants. In practice, healers-bone graders more often used a plant called mumiyo, which was one of the most healing. Healers themselves collected mummies in the mountains.

Bone grafts in the treatment of patients with information found in the most valuable books and manuscripts in Farsi, Arabic and Turkish.

In order to read such sophisticated books and analyze them, knowledge was required: Farsi and Arabic, the structure of the human body, i.e. anatomical knowledge, properties of medicinal herbs, their chemical composition. Central Asian healers - chiropractors in practice used information blackened out from the scientific works of great experts and medical scientists such as Abu Bakr Rosi (865-925gg), Ibn Sino (980-1037gg), Mahmoud Hakim YayfaniHukandi (born 1851), Mulla Nurmuhama XIX-XX centuries), Hamidjon Ibn Zahidkhon ibn Muhammad Sadykhon Shoshi (1870-1953), Bosithon ibn Zahithon ibn Sadykhon Shoshi (1878-1959).

Mahmoud HakimYaifaniHukandi, having deeply studied oriental medicine and drawing on personal medical experience, writes books under the title $\langle<$ Tarih al-ilog $\rangle>(<<$ Treatment Methods $>>)$ (completed in 1910, published in 1913), $<<$ Konun al-ilog $\gg>(<<$ Laws of healing $>>)$. In these works, the author provides information on various diseases of the human body, on its structure, on practical medicine and pharmacology.

Modern scientists - researchers and specialists seriously interested in the activities of representatives of traditional medicine, tried to use their methods of treatment and use of drugs in modern medicine.

For example, the outstanding scientist of medical science in the field of traumatology and orthopedics Adyl Shakirov, having thoroughly studied the methods of treating bones and grafts, widely used them in practice. < $<$ The famous scientist Adyl Shakirov relied not only on the achievements of Soviet medicine, but also deeply studied folk healing and introduced its best aspects in modern medicine.

For that period, this can be called a kind of heroism >>, says Moshtabib-Khoji Abdujabbor Muhammad Sobir ugli from Tashkent. Having visited 24 cities and 52 regions of Uzbekistan, A. Shakirov, Tashkent, Samarkand, Bukara, Fergana, Andijan, Surkhandarya, Khorezm, Namangan, Karakalpak Autonomous Soviet Socialist Republic, Southern Kazakhstan, cities of neighboring republics of Frunze, Dushanbe, Mari, studied methods of work famous chiropractors.

$\mathrm{He}$ is studying the treatment methods of 76 healers - chiropractors, but considers only 20 chiropractors to be dysfunctional.

In Tashkent, fame was gained by the chiropractors Ibrokhim Shukurov (born in 1871), KomilSalimov (born in 1874), Vosidkhon Zokhidzhonov (born in 1877), Muhammadkarim Mullaobdiev (born in 1890), and Berkin Turmanov (born in 1926). Ibrohim Shukurov, being from the fifth generation of chiropractors, learned the secrets of crafts from his father Shukur and Grandfather Arnabbai. When treating patients, he was guided by the manuscripts and scientific works of experts in medical science, like Avicenna. Until 1959, until the end of his death, he was engaged in healing. The chiropractor from Tashkent KomilSalimov (nicknamed Kamil the Bald) gave 36 years of his life to the craft of bone-crushing, rumors about the "lightness" of his hands went all over the outskirts.

Healer-chiropractor V. Zakhidzhanov studied at the madrassah of Bukhara, perfectly mastering the Arabic language and Farsi. He had more than 300 books on medicine in his personal library; together with historian A.A.Semenov, he collected many unique manuscripts and began translating them. Muhammadkarim Mullaobdiev was the only chiropractor to open a five-bed hospital for patients in his house.

Abdulladzhan Tashmatov from Margilan, Kasymbay Akhmedov, Yorkulbay Ulmasbayevs from Namangan, SobirKurezov, NiyazjanKurezov, Kazak Khasanov from Khorezm were especially popular in the Ferghana Valley.

S. Kurezov came from the seventh generation of chiropractors, he studied this craft with his father for 8 years.

Kashkadarya chiropractors Khalil Majidov, Palvan Samadov, Ismail bobo Klychev gained wide fame among the people. In Samarkand, chiropractors UstoTukhtaHaknazar ugli, Khasan Obidovy are popular. UstoTukhtaHaknazar ugli was born in 1870 . He practiced medicine for 60 years. H. Majidov began his activity in 1921, for 30 years heals the sick and only his son teaches his craft. He was educated at a 
religious school. Hassan Obidov in 1902 marries the daughter of the bone-crusher Mamat Najabov, and learns the craft of bone-crusting from his father-in-law. He treated patients without assistance, in rare cases they helped him.

Abu Tuxanbaev and Nishongul Banibetova also engaged in chiropractic for many years, thanks to this they won the love and respect of the people. Abu Tuxanbaev was born in a shepherd family, he studied this craft independently. Even as a shepherd, he began this activity, setting up the bones of injured animals.

\section{CONCLUSION}

In the practice of alternative treatment, rational actions are found, based on the results of centuries of natural experience. So, bone-crushing, considered one of the main directions of folk medicine, despite the prohibitions of persecution in Soviet times, continued to live as a heritage, enriching itself with new information, experience and a valuable source for modern medicine from year to year.

\section{REFERENCES}

1. Karimov I.A. Uzbekistan is on the threshold of the 21st century. Uzbekistan 1992.S8.

2. Khabieva T.Kh. The development of Kazakh medicine in various historical periods. Abstract. Diss. Candidate of Science Bishkek. 2002. P.13.

3. Sayfulmulukov I.K. On the issue of tabibism in Uzbekistan. \ Medical meaning of Uzbekistan. 1923.№10.P.63-69.

4. Masterpieces of medicine. Tashkent. Ibn Sina. Publishers 1993. S. 101-112.

5. Oriental medicine. Prepared for publication by a translator KhamidullaHikmatullaev. T; A. Kadiri. Publishing House of National Heritage. 1994. S. 104-105.

6. Mostabib-Haji Abdujabbor Muhammad Sabir ugli. Tabibism past century. T; Tashkent. Davrpress. 2007. P.57

7. Shakirov A.Sh. Kostopravstva in Central Asia and measures to combat it. T.Meditsina. 1964. S.6-7.

8. Shakirov A.Sh., Luzina E.V. On the history of the treatment of fractures and dislocations according to eastern folk medicine. T.Meditsina. S.53-62.

9. Field Records. Kashkadarya region, Chiyal village, Oktunli village.

10. Shakirov A.Sh., Luzina E.V. Above source. S.40-52. 